\title{
ŚLADY WIERZEŃ POGAŃSKICH NA PRZYKLADZIE ZNALEZISK Z OSTROWA LEDNICKIEGO
}

\author{
TRACES OF PAGAN BELIEFS AS EXEMPLIFIED \\ BY FINDS FROM OSTRÓW LEDNICKI
}

\begin{abstract}
The article presents an analysis of finds and information attributed to the pre-Christian religion in Ostrów Lednicki and the ancillary facilities. To this end, a number of finds from the first half of the $10^{\text {th }}$ to the early $12^{\text {th }}$ centuries were described and interpreted. They include a piece of a gold amulet locket, a utensil made of clay with the swastika and an encircled cross, a buried horse, wooden horse figures, an ornamental element of a knife sheath ferrule, a round rattle and a wooden structure with cornerstone offerings. By means of comparative studies and analyses of the archaeological excavations in Ostrów Lednicki and its vicinity (Dziekanowice, Moraczewo), the authors conclude that in this area, a pagan cult centre could have existed in the late $9^{\text {th }}$ and the early $10^{\text {th }}$ centuries at the latest, related most probably to Svarog /Svarozic, god of the Sun, the home, and a divine blacksmith.
\end{abstract}

Keywords: Ostrów Lednicki, pre-Christian religion, Svarog /Svarozic, knife sheath ferrule, gold amulet locket, cornerstone offerings, round rattle, swastika, cult of the horse and the sun

Historyczne przekazy pisane odnoszące się do religii słowiańskiej są nieliczne. Zachowane źródła dotyczą głównie terenów Połabszczyzny, Pomorza Zachodniego oraz Rusi. W większości pochodzą z przełomu X i XI w., końca XI i z XII w., czyli z czasów, gdy trwała już chrystianizacja tych ziem. Informacje te odnotowywali chrześcijańscy duchowni, więc mogą być one niepełne i zapewne zniekształcone (Gieysztor 1982; Łowmiański 1986; Gąsowski 1993, s. 13; Słupecki 2006, s. 63 i n.; Ożóg 2016, s. 56 i n.). Stosunkowo rzadkie wzmianki o wierzeniach Słowian uzupełniają badania archeologiczne (odkrywające m.in. miejsca związane z kultem czy wyobrażenia bogów), prace religioznawców, językoznawców i etnologów¹.

* ORCID 0000-0003-3308-0994; Wczesnopiastowska Rezydencja na Ostrowie Lednickim, Muzeum Pierwszych Piastów na Lednicy, Dziekanowice 32,62-261 Lednogóra, e-mail: ol.db@lednica.pl;

** ORCID 0000-0003-3202-4309; Wczesnopiastowska Rezydencja na Ostrowie Lednickim, Muzeum Pierwszych Piastów na Lednicy, Dziekanowice 32, 62-261 Lednogóra, e-mail: ol.at@lednica.pl.

1 Wierzeniom Słowian poświęcono m.in. kilka konferencji, po których wygłoszone referaty opublikowano - por. np.: Wierzenia przedchrześcijańskie... 1993; Sacrum pogańskie... 2010, i publikacje książkowe m.in. Szyjewski 2010; Strzelczyk 2007; Gieysztor 1982; Brückner 1985; Szafrański 1979. 
Dzięki interdyscyplinarnym badaniom oraz studiom komparatystycznym częściowo odtworzono świat słowiańskich wierzeń i obrzędów religijnych oraz niektóre miejsca kultu dawnych plemion (por. np.: Szafrański 1979, s. 387 i n.; Gieysztor 1982; Schuldt 1990; Moździoch 2000, s. 155 i n.; Strzyżewski, Łastowiecki i Kara 2003; Słupecki 2006, s. 63 i n.; Cieślik 2010, s. 61 i n.; Sawicki 2017, s. 641 i n.). Zauważono, że znajdowały się one w charakterystycznych lokalizacjach: przy źródłach, na wzgórzach, brzegach dużych jezior, wyspach, w sąsiedztwie dużych głazów, starych dębów i w otaczających je gajach (patrz np.: Makiewicz i Prinke 1981; Lewczuk 2000, s. 195 i n.; Słupecki 2000, s. 39 i n.; Cieślik 2010, s. 28 i n.). Oznaczano je poprzez specjalne wygrodzenia świętej przestrzeni (locus sanctus), w których obrębie mogły znajdować się posągi bogów. W wierzeniach ważną rolę pełniły również święte gaje. W pobliżu ośrodków kultu mogły być place, na których zbierali się wierni, pomieszczenia dla świętych zwierząt czy ołtarze do składania ofiar. W niektórych miejscach natrafiono na pozostałości budowli świątynnych (np. Gross Raden) lub kamienne kopce/kurhany (np. Gniezno). Jak zauważył A. Szyjewski - „Słowianie należeli do kultur tradycyjnych, w których nie da się wydzielić odrębnej dziedziny religijnej, gdyż całe ich życie było religią przesiąknięte. Ich świat był przez nich przeżywany jako święty, żywy, nieustannie odradzający się organizm [...]. Od chwili narodzin, poprzez kontakty ze zjawiskami przyrody i elementami kultury, nabranie zwyczajów żywieniowych, rodzinnych, agrarnych po śmierć, byli zanurzeni w swojej rzeczywistości” (2010, s. 13).

Ostrów Lednicki wpisuje się w różne kategorie identyfikujące miejsca sakralne: powtórzenia, odkrycia, symboliki nadzwyczajności (Cieślik 2010, s. 73, por. Makiewicz i Prinke 1981). Spośród nich najbardziej przystająca do tego miejsca jest kategoria symboliki nadzwyczajności, związana głównie z symboliką środka, którą można odnosić m.in. do wyróżniających się od otoczenia obiektów naturalnych, podobnie jak góry i drzewa ${ }^{2}$ (Chudziak 2010, s. 290). Ponadto na najwyższym wyniesieniu w południowej części wyspy już w 1. połowie X w. wzniesiono niewielki wał o konstrukcji drewniano-ziemnej (Kara 2009, s. 353). Możliwe, że umocnienia te stanowiły kolejną (obok wody i wyniesienia) barierę oddzielającą ewentualne miejsce obrzędowo-kultowe od otoczenia (por. Lewczuk 2000, s. 201; Chudziak 2010, s. 300 i n.).

Materialne ślady dawnych tradycji oraz wierzeń są odkrywane na Ostrowie Lednickim, który znany jest jako jedno z ważniejszych miejsc związanych z początkami państwa polskiego, gdzie powstały m.in. jedne z najstarszych chrześcijańskich i świeckich budowli kamiennych (Ostrów Lednicki u progu... 1993; Wczesnośredniowieczne mosty... 2000; Górecki 2001; Wczesnośredniowieczne mosty... 2014; Ostrów Lednicki... 2016). W kaplicy lednickiego palatium prawdopodobnie został ochrzczony książę Mieszko I (por. np.: Górecki 2015; 2016;

2 Ostrów Lednicki z kilkoma naturalnymi wzniesieniami był zapewne dobrze widoczny ze znacznej odległości na tle otaczającego, stosunkowo płaskiego terenu. 
Żurowska 2016). Czy jednak wcześniej, w czasach przed wprowadzeniem religii chrześcijańskiej znajdowało się tu miejsce kultu?³. Na podstawie obecnego stanu wiedzy trudno jednoznacznie odpowiedzieć na to pytanie. Wiemy, że przed powstaniem dużego założenia grodowego i przyjęciem chrztu przez Mieszka I wyspę użytkowano osadniczo, co potwierdzają datowane na VII-IX w. warstwy kulturowe z fragmentami ceramiki oraz jamą-ziemianką i skupisko kamieni-palenisko (Górecki, Łastowiecki i Wrzesiński 1994, 24 i n.; Banaszak i Tabaka 2016a, s. 131). Natomiast w 3. ćwierci IX w. wybudowano na Ostrowie Lednickim pierwsze umocnienia. W południowo-zachodniej części wyspy, na najwyższym wyniesieniu powstał wówczas niewielki gród o średnicy około $40 \mathrm{~m} \mathrm{z}$ zabudową w części wschodniej (Górecki i Łastowiecki 2016, s. 61 i n.; Górecki, Łastowiecki i Wrzesiński 1994, 24 i n.; Banaszak i Tabaka 2016a, s. 131), a około 150 m na północ od umocnień odkryto zabudowę mieszkalną - półziemiankę datowaną na 1. połowę X w. (Banaszak i Tabaka 2016a, s. 136).

W tym wczesnym okresie osadnictwo w otoczeniu Ostrowa Lednickiego najintensywniej koncentrowało się wokół odległego około $3 \mathrm{~km}$ na południowy zachód grodu w Moraczewie (Strzyżewski, Łastowiecki i Kara 2003, s. 76 i n.; Banaszak i Tabaka 2016b, s. 285 i n.). Od 2. połowy X do około połowy XI w. notujemy szczytowy rozwój osadnictwa na Ostrowie Lednickim (tzw. faza rezydencjonalna). Nastąpiła wówczas znaczna rozbudowa umocnień grodu (wały i umocnienia brzegu; por. np.: Górecki 2010, s. 107 i n.; Górecki i Łastowiecki 2016, s. 66 i n.), wzniesiono dwa mosty łączące wyspę z lądem oraz, co najważniejsze - dwie budowle kamienne (pałac z kaplicą baptyzmalną i kościół grodowy; por. np.: Górecki 2001, s. 40 i n.; Kola, Radka i Wilke 2016, s. 107 i n.; Rodzińska-Chorąży 2016, s. 143 i n.; Wrzesiński i Kara 2016, s. 173 i n.). Procesowi zintensyfikowanego osadnictwa na Ostrowie i w jego okolicy (Banaszak i Tabaka 2016a; 2016b; 2016c) towarzyszył upadek znaczenia grodu w Moraczewie (Strzyżewski, Łastowiecki i Kara 2003, s. 90). Wreszcie po wybuchu tzw. reakcji pogańskiej i najeździe księcia czeskiego Brzetysława w latach trzydziestych XI w. cała infrastruktura kompleksu grodowego na wyspie została zniszczona i dopiero około połowy XI w. przystąpiono do częściowej odbudowy tego założenia. Jednak z racji tego, iż cały region stracił dotychczasowe znaczenie - wyspowa rezydencja stała się jedynie siedzibą kasztelana (por. np.: Leśny 1975; Górecki 2001, s. 40 i n.; Banaszak i Tabaka 2016a, s. 135 i n.), a z czasem na części grodowego majdanu założono cmentarz, który funkcjonował do XIV w. (Górecki 2001, s. 67 i n.). Podobnie datowany (połowa XI-XIII w.) jest kolejny cmentarz lednickiego kompleksu w Dziekanowicach (stan. 22). Został on założony na wschodnim brzegu jeziora, zajmując część wcześniejszej osady przymostowej (Wrzesińska i Wrzesiński 1998,

\footnotetext{
${ }^{3}$ Zagadnieniem tym zajmował się wcześniej J. Leśny, przedstawiając swoje tezy w artykule z 1975 r. Jednak w ciągu następnych lat badań wykopaliskowych odkryto wiele kolejnych znalezisk, które można wiązać z wierzeniami przedchrześcijańskimi i ich kontynuacją po 966 roku.
} 
s. 13 i n.; Wrzesiński 2000, s. 91 i n.; Wrzesińska i Wrzesiński 2005, s. 11; Wrzesiński 2016, s. 14).

Kwestię kultowego znaczenia wyspy podjął już kilkadziesiąt lat temu w swoich pracach J. Leśny (1975, s. 121 i n.), analizujący zagadnienia związane z kultem pogańskim na Ostrowie Lednickim. Zajął się m.in. weryfikacją wcześniejszych, znanych z literatury hipotez na temat istnienia na wyspie miejsca kultu pogańskiego. Zanegował twierdzenie o przedchrześcijańskim pochodzeniu ruin lednickich (jako pozostałości świątyni pogańskiej) i drewnianej figurki koziołka (Leśny 1975, s. 119 i n., tam dalsza literatura). Natomiast z wierzeniami pogańskimi wiąże on pochodzące z 2. ćwierci XI w., opisywane wcześniej odkryte w murach palatium „urny z popiołem”, czaszkę ludzką ,przedziurawioną długim żelaznym gwoździem” i (ewentualnie) paleniska odkryte na terenie wyspowego cmentarza. Napisał m.in.: „mimo wszystko nadal brak danych wskazujących na egzystencję na Ostrowie Lednickim ośrodka kultu pogańskiego w dobie przedchrześcijańskiej [...]. Wiele więcej przemawia natomiast na korzyść repoganizacji, któremu to procesowi ulec mogła wyspa po 966 r.” (1975, s. 123). Z tymi wydarzeniami łączy on także odkryte w 1972 r. pozostałości drewnianego budynku z dużym paleniskiem i fragmentami końskich szkieletów ${ }^{4}$.

W nurcie badań związanych ze źródłami materialnymi istotne miejsce zajmują obecnie studia nad różnego typu przedmiotami. Obok fizykalistycznego i idiograficznego ujęcia źródeł podejmuje się również ich ocenę społeczną - sposób funkcjonowania w obrębie dawnych grup ludzkich (Latour 2010, s. 541 i n.; Olsen 2010, s. 561 i n.). Taka próba spojrzenia na niektóre z drobnych ruchomych obiektów odkrytych na Ostrowie Lednickim może, w naszym przekonaniu, przemawiać za funkcjonowaniem na tej wyspie miejsca dawnych praktyk religijnych, chociaż zdajemy sobie sprawę z niejednoznaczności naszych ocen dotyczących świata dawnych rzeczy oraz ich statusów w ówczesnej społeczności (w związku z kultami pogańskimi, ryc. 1).

Serię analizowanych znalezisk ${ }^{5}$ otwiera datowany na 1 . połowę $X$ w. fragment złotej kaptorgi (ryc. 1.6; 2), odkryty w warstwie podwalinowej w południowej części wału, na głębokości około 4,50 m pod powierzchnią darni (Banaszak i Tabaka 2017, s. 1199 i n.). Jego wymiary wynoszą: długość 1,71 cm, wysokość $1,62 \mathrm{~cm}$, grubość blaszki $0,01 \mathrm{~cm}$, waga 1,20 g. Górna część przedmiotu uformowana jest w stylizowaną główkę konika z zaznaczonymi uszami i grzywą, środkową tworzy pas blaszki, a dolną - pas plecionki wykonany z trzech połączonych drucików. Zarówno grzywę konia, krawędzie środkowej blaszki, jak i środkowy drucik plecionki wykonano $\mathrm{w}$ technice filigranu.

\footnotetext{
4 J. Leśny budynek ten datuje na XI w. (1975, s. 127), natomiast w późniejszym opracowaniu jego chronologię przesunięto na 1. połowę XII w. (Górecki, Łastowiecki i Wrzesiński 1994, s. 33-35).

5 Kolejność opisu odkryć uporządkowano pod względem chronologicznym, a następnie podjęto próbę ich interpretacji.
} 


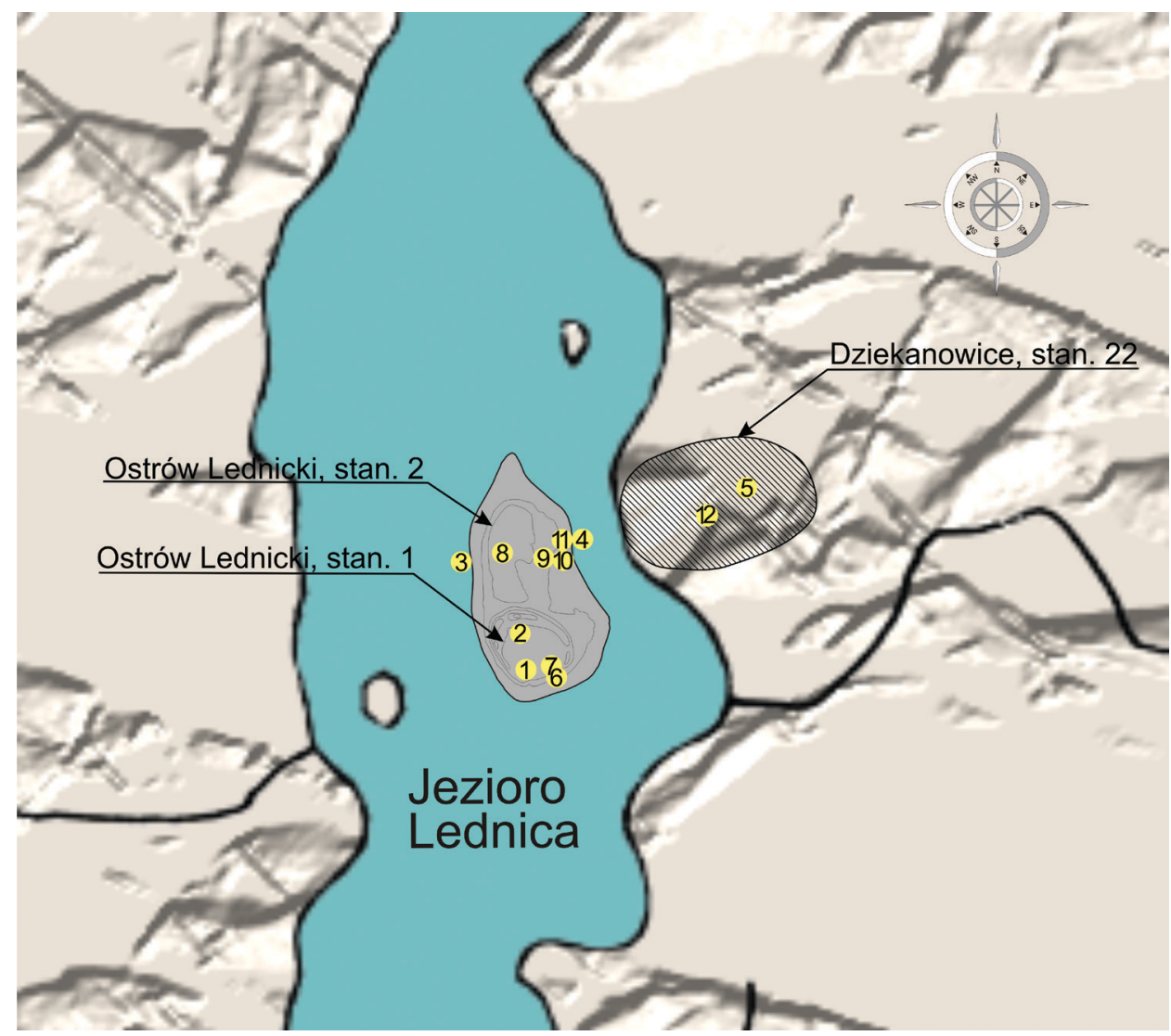

Ryc. 1. Plan sytuacyjny Ostrowa Lednickiego i wschodniego brzegu jeziora Lednica z zaznaczonymi miejscami opisywanych znalezisk:

1 - pałac z kaplica baptyzmalną; 2 - kościół grodowy; 3 - most zachodni; 4 - most wschodni; 5 - cmentarzysko w Dziekanowicach stan. 22; 6 - fragment złotej kaptorgi; 7 - naczynie ceramiczne; 8 - fragment pisanki glinianej; 9 - chata z ofiarami zakładzinowymi; 10 - fragmenty koników z drewna; 11 brązowa pochewka noża; 12 - pochówek konia, opracowanie A. Tabaka

$\mathrm{Z} 2$. połowy $\mathrm{X}$ w. pochodzi duże naczynie gliniane zdobione wizerunkami uznawanymi za solarne (swastyka i krzyż w kole; ryc. 1.7; 3). Odkryto je we wnętrzu półziemianki usytuowanej około $18 \mathrm{~m}$ na północny wschód od kaplicy pałacowej oraz około $15 \mathrm{~m}$ na północ od wewnętrznego stoku wału południowego. Naczynie wykonano z glin żelazistych (z domieszką średnioziarnistego piasku) metodą ręcznego lepienia z przykrawędnym obtaczaniem i wypalono w atmosferze utleniającej na kolor brązowo-beżowo-pomarańczowy. Na jego krawędzi wykonano niewielki wrąb na pokrywkę. Wymiary naczynia: wysokość $43,5 \mathrm{~cm}$, średnica wylewu $45 \mathrm{~cm}$, średnica dna $17,5 \mathrm{~cm}$, największa wydętość $50 \mathrm{~cm}$ (na wysokości $39 \mathrm{~cm}$, licząc 
od dna). Motywy solarne stanowiące jedyny ornament umieszczono tuż pod największą wydętością brzuśca. Półziemianka, w której odkryto to naczynie, mogła pełnić funkcję piwnicy (magazynu), ponieważ odkryto je wraz z fragmentami trzech innych, dużych naczyń zasobowych (Łastowiecki 1997).

Kolejnym z interesujących znalezisk są pochodzące z przełomu X i XI w. szczątki konia umieszczone w jamie oznaczonej dwoma głazami - zlokalizowanej w południowo-wschodniej części funkcjonującej na lądzie przy moście wschodnim osady (ryc. 1.12) (Wrzesińska i Wrzesiński 1998, s. 103 i n., ryc. 4, 5; Makowiecki i Makowiecka 1998, s. 117 i n.). Kształt jamy był zbliżony w rzucie poziomym do kwadratu o wymiarach około $240 \times 240 \mathrm{~cm}$. Zwierzę złożono w jamie w porządku anatomicznym (bez przednich kopyt) i położono na lewym boku, na osi wschódzachód z czaszką skierowaną na wschód ${ }^{6}$. Jak zauważyli odkrywcy (Wrzesińska i Wrzesiński 1998, s. 112), „Można domniemywać, że pochowane w specjalnej jamie zwierzę - koń spełniało przez długi okres czasu (wiek konia określono na 15-18 lat) ważną funkcję. Dla właściciela - użytkownika koń ten był na tyle ważnym, że nie tylko pochował go bardzo starannie, ale dodatkowo oznaczył dwoma głazami”. W tym miejscu warto nadmienić, iż pochówki koni we wczesnym średniowieczu należały do rzadkości, znalezisko z Dziekanowic stan. 22 jest zaś jednym z niewielu znanych do tej pory z terytorium Polski (Makowiecki i Makowiecka 2014, s. 351 i n.).

Serię analizowanych przedmiotów uzupełnia datowana na 2. połowę XI w., odkryta na wyspowym przyczółku mostu wschodniego, bogato zdobiona pochewka z zachowanym fragmentem noża (ryc. $1.11 ; 4 ; 5)$. Wykonano ją ze skóry z brązowym okuciem (Niedzielski i Jakubowski 2017) ornamentowanym na krawędziach pojedynczymi pasami guzków wykonanych techniką puncowania. Najciekawszym i najważniejszym jej elementem jest brązowy pręt o półowalnym przekroju przymocowany do brązowej blaszki trzema brązowymi nitami (ryc. 4). Jego górną część zwieńcza stylizowana postać ludzka z podłużną głową z zagłębionymi, charakterystycznymi, bardzo dużymi oczami, nosem, ustami i zarostem, wąskim korpusem, półkoliście wygiętymi rękami (z zaznaczonymi łokciami) opartymi na biodrach oraz półkoliście wygiętymi nogami (między nimi umieszczony jest jeden z nitów) z zaznaczonymi na nich poziomymi liniami ${ }^{7}$. Pod brodą postaci widoczna jest półkolista linia, która może oznaczać obszycie górnej części koszuli lub naszyjnik (por. np. opis okucia pochewki z Brześcia Kujawskiego, Kaszewscy 1971, s. 390). Drugi koniec pręta jest wygięty pod kątem prostym, nieco pogrubiony u dołu i uformowany w kształcie litery „V” z zawiniętymi na zewnątrz końcami. Pomiędzy opisanymi wyżej elementami, po obydwóch stronach środkowego nitu, niemal

\footnotetext{
${ }^{6}$ Późniejsza jama grobowa (cmentarzysko szkieletowe funkcjonowało na tym terenie od poł. XI w.) uszkodziła fragment czaszki konia.

${ }^{7}$ F. Biermann (2014, s. 392) interpretuje poziome linie umieszczone na nogach postaci jako odwzorowanie przewiązywania spodni przez Słowian.
} 


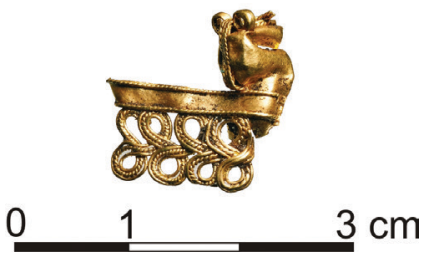

Ryc. 2. Fragment złotej kaptorgi, fot. M. Jóźwikowska

symetrycznie umieszczone są sylwetki dwóch stylizowanych zwierząt (o długich, cienkich korpusach, długich nogach i pyskach, krótkich, uniesionych pionowo, spiczastych ogonach i zaokrąglonych stykających się uszach przypominających aureolę?), prawdopodobnie koni (Рябинин 1981, tab. X, 4-8; Szczepanik 2010, s. 34; por. też Biermann 2014, s. 397), które skierowane są w stronę postaci ludzkiej. Zachowane wymiary pręta wynoszą: długość $8,8 \mathrm{~cm}$, szerokość $0,33 \mathrm{~cm}$, grubość: $0,36 \mathrm{~cm}$, wysokość postaci ludzkiej $1,8 \mathrm{~cm}$.

$\mathrm{Na}$ ten sam okres (2. połowa XI w.) datować możemy odkryty w środkowo-zachodniej części wyspowego podgrodzia fragment (około 1/10) szkliwionej grzechotki guzowatej (ryc. 1.8; 6). To przedmiot wykonany z białej gliny z domieszką drobnoziarnistego piasku, szkliwiony na powierzchni zewnętrznej na kolor zielony o różnych odcieniach. Przed wypałem wykonano otwór, w którym umieszczono gliniany, półkolisty, lekko spłaszczony guzek. Fragmentarycznie widoczne są również ślady po kolejnych trzech otworach na guzki. Zachowane wymiary grzechotki wynoszą około $3,65 \times 2,40 \mathrm{~cm}$, grubość $0,3-0,74 \mathrm{~cm}$, średnica guzka około $0,9 \mathrm{~cm}$, wysokość guzka około $0,36 \mathrm{~cm}$. Z Ostrowa Lednickiego znane są jeszcze cztery inne szkliwione na zielono egzemplarze grzechotek odkryte na grodowym cmentarzysku - trzy z guzkami i jeden bez guzków (Hilczerówna 1950, s. 17-18; Wrzosek 1961, s. 251) oraz trzy następne z cmentarzyska w Dziekanowicach (stan. 22) - jedna guzowata i dwie szkliwione pisanki (Wrzesińska i Wrzesiński 2017, s. 339 i n.).

Dalsze $\mathrm{z}$ interesujących nas przedmiotów to datowane na XI w. fragmenty trzech (?) drewnianych koników (ryc. 1.10; 7) odkrytych w pobliżu brzegu jeziora w środkowo-wschodniej części podgrodzia około 30-40 m na południe od przyczółka mostu wschodniego (Łukaszyk 2012, s. 122). Zarejestrowane zostały one w niewielkiej odległości od siebie (40 cm NS i $110 \mathrm{~cm}$ EW). Różny jest ich stan zachowania, mają one geometryzujące kształty (stylizowana głowa z szyją zbliżone do litery Z) oraz porównywalne wymiary: długość 9-10,5 cm, szerokość 1,5-2,5 cm i grubość 1,4-1,85 cm, średnica otworów 0,47-0,51 cm. Wszystkie posiadają na jednym $\mathrm{z}$ boków ornament w postaci okrągłych dołków (w jednym lub w dwóch rzędach) - na głowach oraz na szyjach (na jednym - na lewym boku konia - ryc. $7 b$ oraz na dwóch na prawym boku - ryc. 7a, c). Oprócz opisanych 


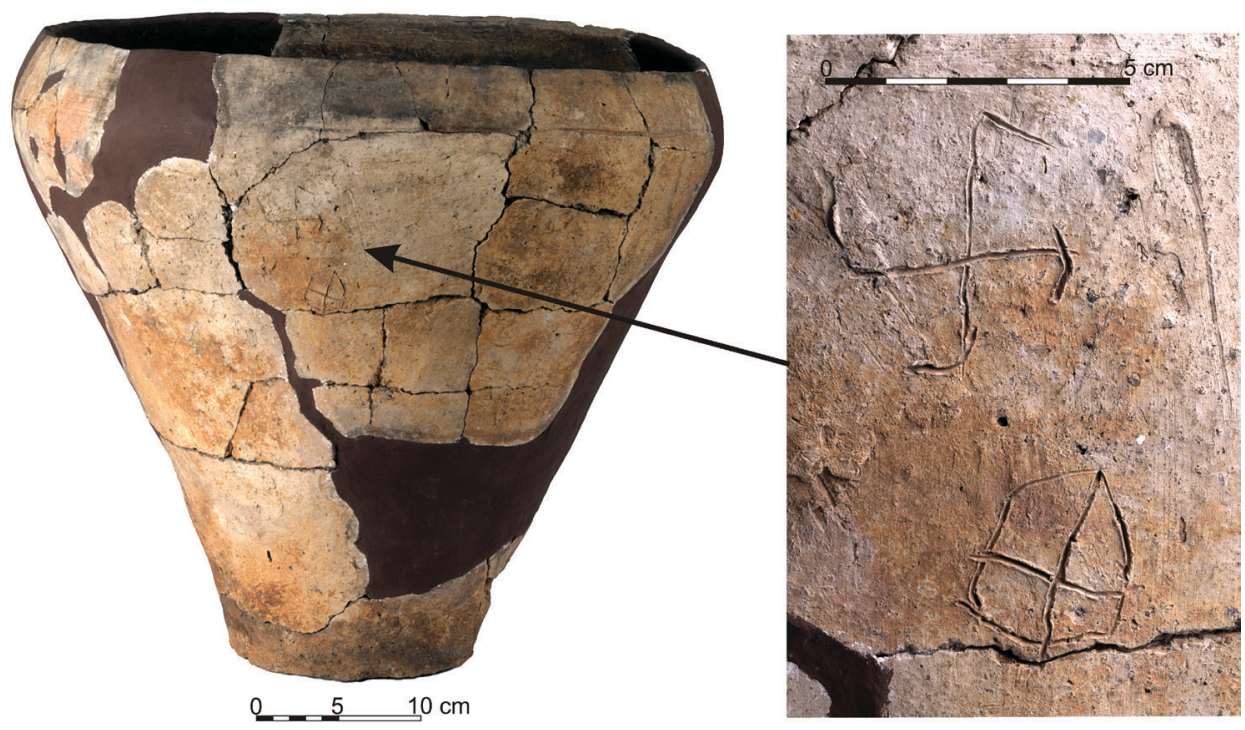

Ryc. 3. Naczynie ceramiczne ze znakami solarnymi, fot. M. Jóźwikowska

wyżej fragmentów, odnotowano w tym skupisku także cztery dalsze kawałki drewna. Na dwóch z nich zaobserwowano analogiczny ornament.

Kolejnymi odkryciami, obok wymienionej grupy drobnych przedmiotów z Ostrowa Lednickiego, mogącymi weryfikować tezę o trwających nadal przedchrześcijańskich wierzeniach, są pozostałości praktyk grzebalnych oraz ofiary zakładzinowe.

Dokumentują je niektóre dary grobowe z cmentarzyska w Dziekanowicach, stan. 22. Są to głównie różnego rodzaju naczynia, w których mogło znajdować się przeznaczone dla zmarłych pożywienie ${ }^{8}$ oraz fragment pochewki noża $z$ okuciem, do którego przymocowano pręt z wygiętym zakończeniem w kształcie schematycznie przedstawionej główki żmii ${ }^{9}$ (Szczepanik 2010, s. 37-38).

Do znalezisk związanych z przedchrześcijańskimi zwyczajami zaliczyć można pochodzące $z$ kasztelańskiej fazy zabudowy podgrodzia Ostrowa Lednickiego pozostałości drewnianego budynku zrębowego o wymiarach około $380 \times 380 \mathrm{~cm}$, datowanego na 1. połowę XII wieku. Jego relikty: pozostałości ścian, glinianej

${ }^{8}$ We wczesnym średniowieczu Kościół nie zabraniał jednoznacznie bogatego wyposażania zmarłych, zakazywał jednak wkładania do grobów jedzenia przeznaczonego dla pochowanych osób (Rębkowski 2007, s. 95).

9 Wspomnianą pochewkę noża odkryto w grobie nr I/97, w którym pochowana została kobieta w wieku Juvenis (18-20 lat). Składamy serdeczne podziękowania Państwu Annie i Jackowi Wrzesińskim za udostępnienie informacji. 


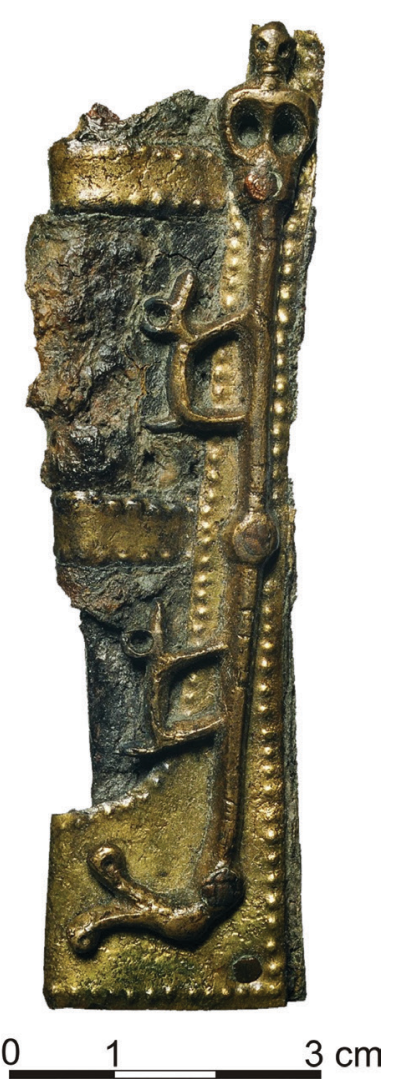

Ryc. 4. Pochewka noża, fot. M. Jóźwikowska

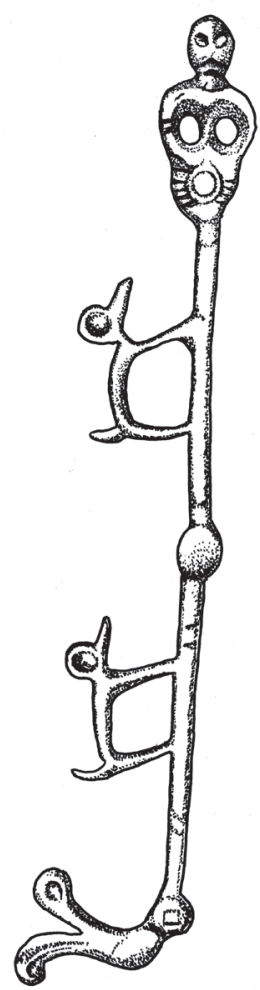

$3 \mathrm{~cm}$

Ryc. 5. Okucie pochewki noża - detal, rys. D. Jagłowska

podłogi-klepiska, centralnie umieszczonego owalnego paleniska o konstrukcji kamiennej (o średnicy około $120 \mathrm{~cm}$ i z grubą warstwą popiołu w starszej fazie oraz o średnicy 180-200 cm w młodszej fazie użytkowania) odkryto w środkowej części podgrodzia (Leśny 1975, s. 124 i n., ryc. 3; Górecki, Łastowiecki i Wrzesiński 1994, s. 35; Banaszak i Tabaka 2016a, s. 141, ryc. VI.11). W połowie długości ściany północnej i w pobliżu środkowej części ściany zachodniej budowli odkryto dwie końskie czaszki wraz z kręgami szyjnymi, a trzecią na zewnątrz budynku, oddaloną około $1 \mathrm{~m}$ od ściany zachodniej. Pierwsza z czaszek (odkryta pod ścianą północną wraz z innymi kośćmi: łopatka, kręgi piersiowe, fragment miednicy) należała do około 15-letniego konia, druga (odkryta pod klepiskiem) - do 9-letniego ogiera, a ostatnia (bez kręgów szyjnych) - do około 10-letniego konia (Leśny 1975 , s. 125). 
Cechą przedstawionej grupy drobnych przedmiotów, budowli i obiektów funeralnych jest powtarzające się w zdobnictwo motywu konia oraz szczątki tego zwierzęcia składane w specjalnie oznaczonych grzebalnych jamach i podwalinach.

We wczesnym średniowieczu przedstawienia koni wykonywano z najróżniejszych materiałów: drewna, bursztynu, gliny czy metali (w tym ze srebra i złota co dodatkowo podkreślało ich wyjątkowy charakter, por. np. Banaszak i Tabaka 2017, s. 1200 i n.). Znaleziska podobizn koni, niekiedy jako osobnych przedmiotów (talizmany?) lub jedynie fragmentów większych obiektów, wiąże się ze szczególnym znaczeniem tego zwierzęcia w religii i obrzędach dawnych Słowian. Jak pisali w swojej pracy z 1998 r. A. i J. Wrzesińscy, „Bogata symbolika konia w wielu kulturach powodowała, iż zajmował on ważne miejsce w wierzeniach i mitologii wielu kultur [...]. Sam koń nie był obiektem kultu. Pełnił jednak ważne funkcje w obrzędach, magii, a także podczas wróżenia [...]. Koń był często rumakiem bóstw i siłą pociągową ich pojazdów. Dzięki temu uważany był za pomost między bóstwami a ludźmi. Na terenie Słowiańszczyzny aspekt pośrednictwa, czy może wstawiennictwa, widoczny jest w szeroko rozpowszechnionych tzw. ofiarach zakładzinowych [...]. Fragment konia (zwłaszcza jego czaszkę) umieszczano pod nowo wznoszonymi wałami obronnymi, pod obiektami mieszkalnymi, a także w obiektach o charakterze kultowym (?). Zwyczaj ofiary zakładzinowej, związany z zakładaniem nowej siedziby, łączy się z początkiem nowego życia, nawiązując do mitu początku" (s. 111, tam dalsza literatura; por. też np. Kowalski 2007, s. 236 i n.). Niekiedy przy posągach bóstw umieszczano przynajmniej elementy rzędu końskiego, np. uzda i siodło w Arkonie (Leśny 1975, s. 128).

Opisane wyżej znaleziska z Ostrowa Lednickiego i jego otoczenia można różnorodnie interpretować. Nie jest możliwe jednoznaczne wyjaśnienie pochówku konia, usytuowanego przy osadzie w Dziekanowicach (stan. 22). Może to był rodzaj ofiary zakładzinowej chroniącej ją przed światem zewnętrznym, jednak równie prawdopodobne jest to, iż $\mathrm{w}$ ten właśnie szczególny sposób zostało pochowane zwierzę bardzo bliskie swojemu właścicielowi lub nawet symbolicznie - zamiast niego (por. Wrzesińska i Wrzesiński 1998, s. 111). Biorąc jednak pod uwagę znaczną wielkość konia i nieczęsty sposób postępowania z nim po śmierci, można także upatrywać w nim wyjątkowe zwierzę, które mogło być wykorzystywane m.in. do celów wróżebnych (Labuda 2003, s. 174; Makowiecki i Makowiecka 2014, s. 365; Biermann 2014, s. 394).

Końskie czaszki odkryte pod ścianami drewnianego budynku mogły pełnić funkcję ofiary zakładzinowej. Podobne było przypuszczalnie znaczenie fragmentu złotej kaptorgi umieszczonej w podwalinie wału grodowego ${ }^{10}$. Miejsca, pod który-

${ }^{10}$ Umieszczenie w podwalinie wału grodowego fragmentu złotego wyobrażenia konia mogło mieć wieloraką symbolikę, mianowicie - ofiara zakładzinowa w postaci konia zapewnić miała bezpieczeństwo i ochronę, a złoto jako symbol władzy, ognia i słońca mogło potęgować ochronną moc, a także symbolicznie łączyć się z jednym ze słowiańskich bogów - Swarogiem/Swarożycem (bóstwem ognia 


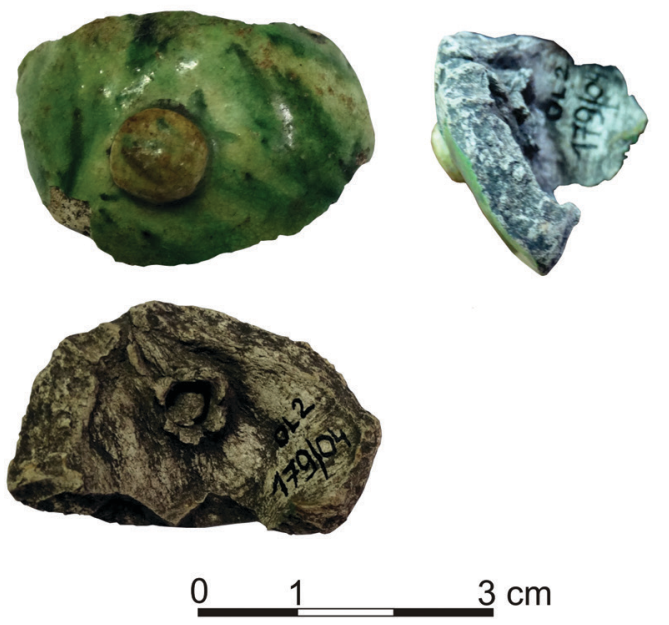

Ryc. 6. Fragment grzechotki glinianej, fot. A. Tabaka

mi złożone były ofiary, miały szczególny charakter, oddzielając obszar znany i oswojony od świata zewnętrznego - obcego i groźnego.

Najprawdopodobniej z wierzeniami wiązać można również znalezisko drewnianych figurek koni z Ostrowa Lednickiego, na co wskazuje zdobiący je ornament okrągłych dołków wiązany z symboliką słońca (Filipowiak 1993, s. 34). E. Choińska-Bochdan (2004, s. 454), negując interpretacje podobnych znalezisk z Gdańska jako zabawek dziecięcych, doszła do wniosku, iż mogą to być jednak przejawy kultu konia i związanych z tym obrzędów, praktykowanych nawet w czasach po przyjęciu chrześcijaństwa. Figurki mogły być także traktowane jako amulety lub składane w miejsce żywych zwierząt jako wota (Łukaszyk 2012, s. 131).

Wreszcie ze światem dawnych wierzeń łączy się zdobiona wyobrażeniami figuralnymi pochewka noża z Ostrowa Lednickiego ${ }^{11}$. Według I. Gabriela (1988, s. 189 i n.; 2000, s. 139), na podobnym do lednickiego okuciu z Oldenburga, schematycznie

niebiańskiego, czyli słońca) oraz jego białym koniem (por. Gieysztor 1982, s. 127 i n.; Banaszak i Tabaka 2017, s. 1201).

${ }^{11} \mathrm{Na}$ podstawie dostępnej literatury (Szczepanik 2010; Biermann 2014; Kowalska 2016) znamy dzisiaj 20 podobnych znalezisk okuć pochewek noży z mniej lub bardziej rozbudowanym wątkiem ikonograficznym. Są to okucia (rozbudowane) z Oldenburga, Brześcia Kujawskiego, Schwedt nad Odrą, Ostrowa Lednickiego, Melzow oraz (prostsze) z Dziekanowic, Kałdusa (2 egz.), Sowinek, Tomic, Bodzi, Łączyna Starego, Dębiny, Brzegu (2 egz.), Poddębic (2 egz.), Psar (2 egz.) i Wolina-Młynówki. Ponadto należy do tej liczby dołączyć jeszcze niewielkie fragmenty czterech kolejnych okuć pochewek z Giecza, z których dwa kształtami zwierząt zbliżone są do okuć z Brześcia Kujawskiego i Oldenburga (składamy podziękowania Pani mgr Teresie Krysztofiak za informację o znaleziskach z Giecza). Znaczącą różnicą pomiędzy zakończeniem okucia pochewki z Oldenburga i innych jest to, 
przedstawiono słowiańską wizję kosmologii ze świetlistym śladem wozu i stojącym na szczycie Swarogiem (bogiem słońca) przemierzającym wszystkie poziomy kosmosu. Drugi koniec osi tego okucia zwieńcza zaś odzwierciedlenie niebiańskiego woźnicy na wozie. Nieco inaczej tłumaczy ten motyw P. Szczepanik (2010, s. 31 i n.), który widzi tam świętą oś łączącą trzy poziomy kosmosu: niebo, ziemię i podziemia, a na szczycie osi widnieje postać Peruna - bóstwa nieba i piorunów, sprawującego władzę nad całym światem, natomiast w dolnej części osi zauważa Trzygława jako wcielenie Welesa - boga zaświatów. Umieszczone w środkowej partii osi okucia z Oldenburga konie są według obydwóch autorów pośrednikami pomiędzy światem ludzi i bogów.

Autorzy niniejszego opracowania, posiłkując się wcześniej opisanymi zabytkami ornamentowanymi, wizerunkami koni, ich rzeźbami oraz ofiarami i pochówkami z wyspy i jej sąsiedztwa, przychylają się raczej do interpretacji I. Gabriela, widząc w głównej postaci lednickiego okucia władczego Swaroga, a na dolnym zakończeniu pręta (symbolizującego ślad wozu) bardzo uproszczonej podobizny tegoż samego boga (jako woźnicy) w otoczeniu dwóch koni.

Kolejnym elementem, który ewentualnie można wiązać z kultem Swaroga/Swarożyca (słońca) jest odkryte na lednickim grodzie gliniane naczynie z ornamentem prawostronnej swastyki i krzyża w kole. Obydwa z tych wyobrażeń symbolizują słońce. Ponadto prawostronna swastyka to oznaka wzrostu, szczęścia i białej magii (Kopaliński 1990, s. 407; Oesterreicher-Mollwo 1992, s. 153), a krzyż w kole zdrowia i życia (Kopaliński 1990, s. 174; Oesterreicher-Mollwo 1992, s. 77).

Wreszcie ostatnie z wymienionych wyżej znalezisk, które można łączyć z religią przedchrześcijańską, to fragment szkliwionej na zielono grzechotki guzowatej, odkrytej w trakcie badań wykopaliskowych prowadzonych na lednickim podgrodziu, kilkadziesiąt metrów na zachód od chaty z czaszkami końskimi. Funkcja tych przedmiotów jest niejednoznaczna. Część badaczy uważała je za dziecięce zabawki (por. Kaczmarek 1998, s. 558 - tam dalsza literatura). Niektórzy widzieli w tych przedmiotach zabawki o charakterze obrzędowym używane do odstraszania złych mocy (Hilczerówna 1950, s. 15 i n.; Kostrzewski 1968, s. 217). Natomiast w nowszych opracowaniach (Kaczmarek 1998, s. 558; Ślusarski 2004, s. 92-93; Wrzesińska i Wrzesiński 2017, s. 339 i n.) funkcję grzechotek wiąże się z obrzędami o charakterze magiczno-kultowym. Moc ich działania zwiększać mógł również zielony (w różnych odcieniach) kolor szkliwa, który symbolizuje m.in. życie i jego odrodzenie, nieśmiertelność, zdrowie, obfitość, płodność (Kopaliński 1990, s. 492 i n.; Oesterreicher-Mollwo 1992, s. 183 i n.; Cirlot 2012, s. 474).

Przedstawiona interpretacja znalezisk z Ostrowa Lednickiego i jego otoczenia i ich związek z religią przedchrześcijańską może wskazywać na istnienie na wyspie miejsca kultu już w okresie przedpaństwowym (Kara 2009, s. 353 i n.), repogani-

iż jedynie ta z Oldenburga ma prostą oś, natomiast w pozostałych dolne zakończenia (jeśli są zachowane) są łukowato wygięte. 


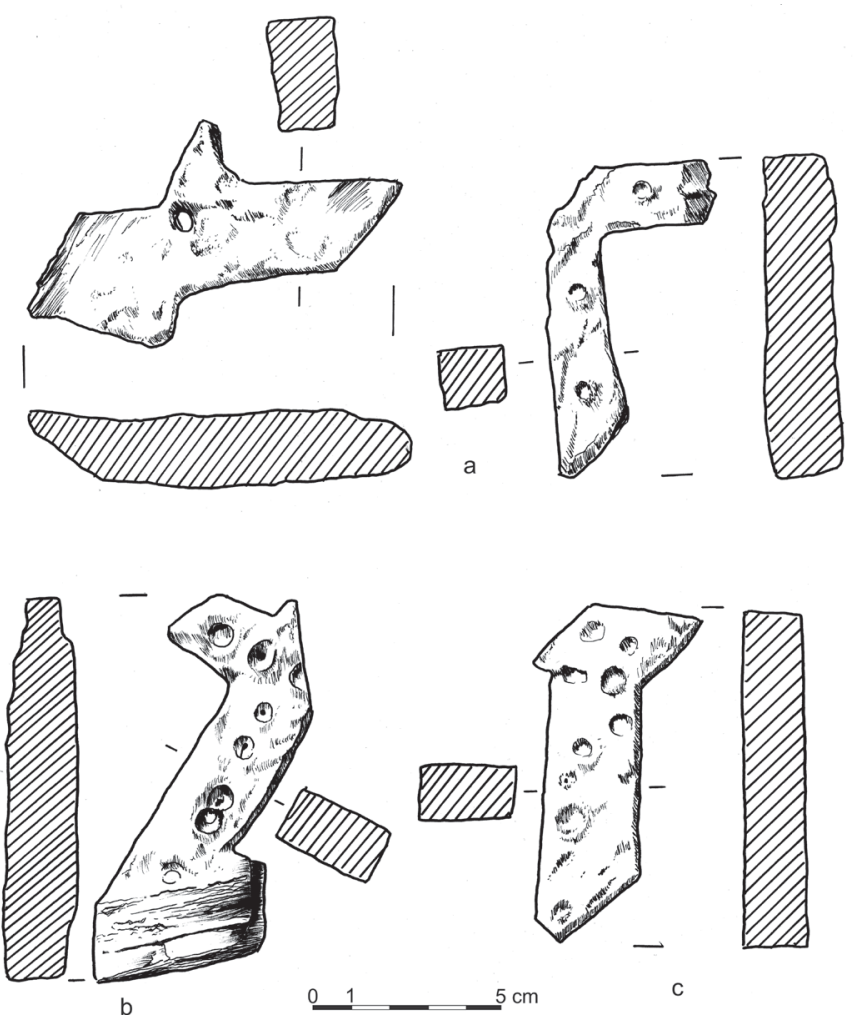

Ryc. 7. a - konik drewniany nr inw. 66/75; b - konik drewniany $\mathrm{nr}$ inw. 67/75; c - konik drewniany $\mathrm{nr}$ inw. $68 / 75$, rys. D. Jagłowska

zacji w latach trzydziestych XI w. (Leśny 1975, s. 123) i przeżywania się dawnych wierzeń aż po wiek XII. Argument ten wzmacnia charakterystyczne położenie Ostrowa (w obrębie zbiornika wodnego) oraz topografia wyspy, której cechą jest kilka naturalnych wyniesień (widocznych zwłaszcza od strony zachodniej). Wyniesienia te jako szczególny element krajobrazu, podobnie jak góra czy drzewo wpisują się w kategorię symboliki nadzwyczajności (Makiewicz i Prinke 1981, s. 63; Sikora 2010, s. 255). Przypuszczać można, że podobnie jak w przypadku innych miejsc (np. Góra Lecha w Gnieźnie, Ślęża), również i na Ostrowie Lednickim nastąpiła kontynuacja charakteru świętego miejsca (Strzelczyk 2010, s. 23 ${ }^{12}$; Cieślik 2010, s. 75; Sikorski 2010, s. 411). Na najwyższym wyniesieniu wybudowano

12 ,przez Jana Długosza, została poświadczona tradycja o istnieniu silnego ośrodka kultu pogańskiego w Gnieźnie. Jeszcze wcześniejszą i w tym przypadku bez wątpienia autentyczną tradycję dotyczącą Ślęży przekazał już wspomniany Thietmar. W obu przypadkach uważa się, że zbudowanie tam chrześcijańskich ośrodków sakralnych [...] spowodowane było koniecznością uświęcenia tych miejsc i przeciwdziałania obecnym tam wcześniej pogańskim mocom”. 
w okresie przyjmowania nowej, chrześcijańskiej wiary pałac z kaplicą baptyzmalną, a na nieco niższym - kościół grodowy (Górecki 2001, s. 40 i n.; Kara 2009, s. 353 i n.; Rodzińska-Chorąży 2016, s. 143 i n.; Wrzesiński i Kara 2016, s. 173 i n.).

Z czasami tzw. reakcji pogańskiej (lata trzydzieste XI w.) i jej długotrwałego przeżywania w świadomości użytkowników wyspy łączyć można relikty znacznie późniejszej (początek XII w.) drewnianej chaty, pod której ścianami odkryto końskie czaszki, a w centralnej części usytuowane zostało znacznej wielkości palenisko. Możliwe, że budynek ten pełnił funkcje kultowe (podobnie interpretował funkcję tej budowli J. Leśny, 1975, s. 134), a wzniesiony został w pobliżu miejsca o „szczególnym” znaczeniu, czego świadectwem mogą być odkryte nieopodal drewniane figurki koników zdobione elementami solarnymi ${ }^{13}$.

Znacznie wcześniejsze od wyspowego budynku kultowego są odkrycia z majdanu grodu w Moraczewie związanego z zachodnią otuliną jeziora Lednica. W trakcie badań wykopaliskowych odsłonięto tam m.in. relikty dwóch dużych budynków drewnianych, których powierzchnie wynosiły $180 \mathrm{~m}^{2}$ i $140 \mathrm{~m}^{2}$, użytkowanych w ciągu dwóch faz funkcjonowania grodu (na przełomie IX/X w. - większy z budynków i w 2. ćwierci X w. - mniejszy z nich, wzniesiony na miejscu starszego). W ich obrębie odkryto pozostałości kilku palenisk, a przestrzeń wewnętrzna nosiła ślady podziału. Może to świadczyć o kultowym charakterze zarówno samych budowli - hal spełniających funkcje biesiadno-kultowe, jak i grodu, który w przeciwieństwie do otaczających go osiedli zapewne nie był zamieszkiwany (jak się przypuszcza) przez większą grupę ludzi (Strzyżewski, Łastowiecki i Kara 2003, s. 90; Banaszak i Tabaka 2016b, s. 286 i n.). Około połowy X w. został on spalony (celowo?), a okoliczną ludność przemieszczono w pobliże Ostrowa Lednickiego, który wyróżniał się zarówno jako naturalne miejsce ochronne, jak i szczególne ze względów kultowych. W obrębie budowli kultowej z młodszej fazy funkcjonowania grodu w Moraczewie odkryto dwie żelazne posrebrzane ostrogi i nieużywane wędzidło, które zinterpretowano jako rodzaj ofiary zakładzinowej (Strzyżewski, Łastowiecki i Kara 2003, s. 89). Przedmioty te, bezpośrednio związane z użytkowaniem konia jako wierzchowca, mogły zostać złożone w ofierze zamiast tego zwierzęcia. Możliwe więc, że odkryte na Ostrowie Lednickim ofiary zakładzinowe stanowić mogą nawiązanie do tego samego nurtu wierzeń.

Zaprezentowane znaleziska z Ostrowa Lednickiego i jego otoczenia oraz ich analiza wskazują na możliwość funkcjonowania tego zespołu jako materialnego świadectwa dawnych wierzeń - kultu konia oraz wiary w moc słońca. Motyw

\footnotetext{
13 Należy przy tym pamiętać, iż od lat trzydziestych XI w. Ostrów Lednicki stracił swoje polityczne znaczenie. Infrastruktura wyspy została znacznie zniszczona (m.in. spalono mosty), co przyczyniło się do zmiany szlaku z Poznania do Gniezna i jej izolacji. Okoliczności te mogły się przyczynić do przynajmniej kilkudziesięcioletniego przetrwania elementów wierzeń pogańskich w tym miejscu.
} 
konia występuje tu pod różnymi formami na przestrzeni kilkuset lat ${ }^{14}$. Uwzględniając ponadto niektóre $\mathrm{z}$ charakterystycznych cech kilku poddanych analizie przedmiotów - złoto i ornament okrągłych dołków, można je łączyć z kultem solarnym. Z tym samym kultem wiążą się również motywy swastyki i krzyża umieszczonego w kole, które zdobiły duże naczynie gliniane odkryte w południowej części grodu. Połączenie opisanych informacji wraz z interpretacją okucia pochewki noża autorstwa I. Gabriela może wskazywać na istnienie na wyspie lednickiej miejsca kultu związanego ze Swarogiem/Swarożycem - bogiem słońca i ogniska domowego, będącym również boskim kowalem ${ }^{15}$.

\section{LITERATURA}

Banaszak D., Tabaka A. 2008, Pozostałości działalności gospodarczej na zapleczu grodu na Ostrowie Lednickim, „Studia Lednickie”, t. 9, s. 115-131.

Banaszak D., Tabaka A. 2016a, Drewniane budownictwo mieszkalne, w: Ostrów Lednicki. Rezydencjonalno-stołeczny ośrodek pierwszych Piastów, Z. Kurnatowska, A.M. Wyrwa (red.), Warszawa, Instytut Archeologii i Etnologii PAN, s. 131-141.

Banaszak D., Tabaka A. 2016b, Kompleks osadniczy i pozostałości działalności gospodarczej wczesnośredniowiecznego centrum, w: Ostrów Lednicki. Rezydencjonalno-stołeczny ośrodek pierwszych Piastów, Z. Kurnatowska, A.M. Wyrwa (red.), Warszawa, Instytut Archeologii i Etnologii PAN, s. 285-297.

Banaszak D., Tabaka A. 2016c, Analiza stratygrafii i chronologii w rejonie tzw. II kościoła (na podstawie badań w latach 1983-1984), w: Ostrów Lednicki. Rezydencjonalno-stołeczny ośrodek pierwszych Piastów, Z. Kurnatowska, A.M. Wyrwa (red.), Warszawa, Instytut Archeologii i Etnologii PAN, s. 243-257.

Banaszak D., Tabaka A. 2017, Equs aureus - fragment złotej kaptorgi z wizerunkiem konia z Ostrowa Lednickiego, w: Gemma Gemmarum. Studia dedykowane Profesor Hannie Kóčce-Krenz, Część druga, A. Różański (red.), Poznań, Wydawnictwo Poznańskiego Towarzystwa Przyjaciół Nauk, s. $1199-1206$.

Biermann F. 2014, Ein „, Götterbildbeschlag” aus der Uckermark als Zeugnis mittelalterlicher Glaubenvorstellungen im nordwestslawichen Raum, „Praehistorische Zeitschrift”, 89 (2), s. 390-403.

Brückner A. 1985, Mitologia słowiańska i polska, Warszawa, Państwowe Wydawnictwo Naukowe.

Choińska-Bochdan E. 2004, Ceramiczny konik z Gniewu nad Wisła-przedmiot zabawy czy magii?, w: Archeologia et historia urbana, R. Czaja (red.), Elbląg, Muzeum w Elblągu, s. 451-455.

Chudziak W. 2010, Przestrzeń pogańskiego sacrum w krajobrazie przyrodniczo-kulturowym Stowian pomorskich, w: Sacrum pogańskie - Sacrum chrześcijańskie. Kontynuacja miejsc kultu we wczesnośredniowiecznej Europie Środkowej, K. Bracha, Cz. Hadamik (red.), Warszawa, Wydawnictwo DiG, s. 289-317.

Cieślik J. 2010, Uwagi o stanie badań nad miejscami kultu pogańskiego Słowian na ziemiach polskich, w: Sacrum pogańskie - Sacrum chrześcijańskie. Kontynuacja miejsc kultu we wczesnośredniowiecznej Europie Środkowej, K. Bracha, Cz. Hadamik (red.), Warszawa, Wydawnictwo DiG, s. 27-80.

${ }^{14} \mathrm{~W}$ materiale archeozoologicznym z Ostrowa Lednickiego odnotowano szczątki około 30 koni. Wśród nich wyróżniono podgrupę koni niskich (poniżej $131 \mathrm{~cm}$ w kłębie) oraz wyższych (do $143 \mathrm{~cm}$ ). Były to głównie zwierzęta juczne i pod wierzch, a ich mięso konsumowano bardzo rzadko (Makowiecki 2001, s. 99).

15 Warto zwrócić uwagę na fakt, iż na terenie wspomnianej wcześniej osady w Dziekanowicach na wschodnim brzegu jeziora, na granicy której zlokalizowany był pochówek konia, odkryto pozostałości dymarek i kuźni (Banaszak i Tabaka 2008, s. 120 i n.). 
Cirlot J.E. 2012, Stownik symboli, Wydawnictwo Znak, Kraków.

Filipowiak W. 1993, Stowiańskie wierzenia pogańskie u ujścia Odry, w: Wierzenia przedchrześcijańskie na ziemiach polskich, M. Kwapiński, H. Paner (red.), Gdańsk, Muzeum Archeologiczne w Gdańsku, s. $19-47$.

Gabriel I. 1988, Hof- und Sakralkultur sowie Gebrauchs- und Handelsgut im Spiegel der Kleinfunde von Starigard/Oldenburg, „Bericht der römisch-germanischen Kommission“, Band 69, s. 103-291.

Gabriel I. 2000, Kosmologisches Bildprogramm als Messerscheidenbeschlag, w: Europas Mitte um 1000, A. Wieczorek, H.-M. Hinz (red.), Stuttgart, Theiss, s. 139.

Gąsowski J. 1993, Między pogaństwem a chrześcijaństwem, w: Wierzenia przedchrześcijańskie na ziemiach polskich, M. Kwapiński, H. Paner (red.), Gdańsk, Muzeum Archeologiczne w Gdańsku, s. 12-18.

Gieysztor A. 1982, Mitologia Stowian, Warszawa, Wydawnictwa Artystyczne i Filmowe.

Górecki J. 2001, Gród na Ostrowie Lednickim na tle wybranych ośrodków grodowych pierwszej monarchii piastowskiej, „Biblioteka Studiów Lednickich”, t. 7, Poznań.

Górecki J. 2010, Brzegowe umocnienia obronne Ostrowa Lednickiego, „Studia Lednickie”, t. 10, s. 107-127.

Górecki J. 2015, Chrzest na Ostrowie Lednickim, Lednica, Muzeum Pierwszych Piastów na Lednicy.

Górecki J. 2016, Baseny chrzcielne z Ostrowa Lednickiego w świetle analizy źródeł archeologicznych, w: Miejsca chrztów, urządzenia baptyzmalne i ceremoniat chrzcielny od starożytności chrześcijańskiej do soboru trydenckiego, A.M. Wyrwa (red.), Poznań-Dziekanowice, Wydawnictwo Poznańskiego Towarzystwa Przyjaciół Nauk, s. 109-152.

Górecki J, Łastowiecki M. 2016, Konstrukcje obronne Ostrowa Lednickiego, w: Ostrów Lednicki. Rezydencjonalno-stołeczny ośrodek pierwszych Piastów, Z. Kurnatowska, A.M. Wyrwa (red.), Warszawa, Instytut Archeologii i Etnologii PAN, s. 59-71.

Górecki J., Łastowiecki M., Wrzesiński J. 1994, Wczesnośredniowieczne budownictwo mieszkalne Ostrowa Lednickiego, „Studia Lednickie”, t. 3, s. 21-45.

Hilczerówna Z. 1950, Przyczynki do handlu Polski z Rusia Kijowska, „Przegląd Archeologiczny”, t. 9, s. 8-23.

Kaczmarek J. 1998, Wczesnośredniowieczne przedmioty szkliwione związane z magia z Kruszwicy, w: Kraje słowiańskie w wiekach średnich. Profanum i sacrum, H. Kóčka-Krenz, W. Łosiński (red.), Poznań, Wydawnictwo Poznańskiego Towarzystwa Przyjaciół Nauk, s. 549-560.

Kara M. 2009, Najstarsze państwo Piastów - rezultat przełomu czy kontynuacji? Studium archeologiczne, Poznań, Instytut Archeologii i Etnologii PAN.

Kaszewscy E. i Z. 1971, Wczesnośredniowieczne cmentarzysko w Brześciu Kujawskim, pow. Włocławek, „Materiały starożytne i wczesnośredniowieczne”, t. 1, s. 365-434.

Kola A., Radka K., Wilke G. 2016, Mosty traktu „poznańskiego” i „gnieźnieńskiego” w świetle badań podwodnych (1982-2015), w: Ostrów Lednicki. Rezydencjonalno-stoleczny ośrodek pierwszych Piastów, Z. Kurnatowska, A.M. Wyrwa (red.), Warszawa, Instytut Archeologii i Etnologii PAN, s. 107-129.

Kopaliński W. 1990, Stownik symboli, Warszawa, Wiedza Powszechna.

Kostrzewski J., 1968. Grzechotki wczesnośredniowieczne bez polewy, „Archeologia Polski”, t. 13, s. 211-218.

Kowalska A.B. 2016, Skórzane elementy stroju w pochówkach na wczesnośredniowiecznym cmentarzysku w Bodzi, w: Bodzia. Elitarny cmentarz z początków państwa polskiego, A. Buko (red.), Warszawa, Instytut Archeologii i Etnologii PAN, s. 253-264.

Kowalski P. 2007, Kultura magiczna. Omen, przesą, znaczenie, Warszawa, Wydawnictwo Naukowe PWN.

Labuda G. 2003, Stowiańszczyzna starożytna i wczesnośredniowieczna. Antologia tekstów źródłowych, Poznańskie Towarzystwo Przyjaciół Nauk, Poznań.

Latour B. 2010, Przedmioty także posiadaja sprawczość, w: Teoria wiedzy o przeszłości na tle współczesnej humanistyki, w: E. Domańska (red.), Poznań, Wydawnictwo Poznańskie, s. 525-560.

Leśny J. 1975, W sprawie kultu pogańskiego na Ostrowie Lednickim we wczesnym średniowieczu, „Slavia Antiqua”, t. 21 (1974), s. 119-135.

Lewczuk J. 2000, Sacrum i profanum - na przykładzie wybranych stanowisk archeologicznych z terenów środkowego Nadodrza, w: Człowiek, sacrum, środowisko. Miejsca kultu we wczesnym średniowieczu, 
S. Moździoch (red.), Wrocław, Instytut Archeologii i Etnologii PAN, Oddział we Wrocławiu, „Spotkania Bytomskie" 4, s. 195-206, Wrocław.

Łastowiecki M. 1997, Sprawozdanie z badań wykopaliskowych prowadzonych na Ostrowie Lednickim. Stanowisko 1 - gród, maszynopis w Archiwum MPP na Lednicy.

Łowmiański H. 1986, Religia Stowian i jej upadek (w. VI-XII), Warszawa, PWN.

Łukaszyk A. 2012, Wierzchowce bogów. Motyw konia w wierzeniach Stowian i Skandynawów, Szczecin, Triglav.

Makiewicz T., Prinke A. 1981, Teoretyczne możliwości identyfikacji miejsc sakralnych, „Przegląd Archeologiczny", t. 28, s. 57-90.

Makowiecki D. 2001, Hodowla oraz użytkowanie zwierząt na Ostrowie Lednickim w średniowieczu, „Biblioteka Studiów Lednickich”, t. 6.

Makowiecki D., Makowiecka M. 1998, Analiza archeozoologiczna pochówku konia, „Studia Lednickie”, t. 5, s. 117-126.

Makowiecki D., Makowiecka M. 2014, Faunal remains, w: The Island in Żótte on Lake Zarańskie. Early Medieval Gateway into West Pomerania, W. Chudziak, R. Kaźmierczak (eds), Toruń, Institute of Archaeology, Nicolaus Copernicus University, s. 311-366.

Moździoch S. 2000, Archeologiczne ślady kultu pogańskiego na Śląsku wczesnośredniowiecznym, w: Człowiek, sacrum, środowisko. Miejsca kultu we wczesnym średniowieczu, S. Moździoch (red.), Wrocław, Instytut Archeologii i Etnologii PAN, Oddział we Wrocławiu, „Spotkania Bytomskie” 4, s. 155-191, Wrocław.

Niedzielski P., Jakubowski K. 2017, Archeometryczne badania pochewki noża z Ostrowa Lednickiego (wstępne wyniki badań), maszynopis w Archiwum MPP na Lednicy.

Oesterreicher-Mollwo M. 1992, Leksykon symboli, Warszawa, ROK Corporation SA.

Olsen B. 2010, Kultura materialna po tekście: przywracanie obecności rzeczom, w: Teoria wiedzy o przeszłości na tle wspótczesnej humanistyki, w: E. Domańska (red.), Poznań, Wydawnictwo Poznańskie, s. 561-592.

Ostrów Lednicki. Rezydencjonalno-stołeczny ośrodek pierwszych Piastów 2016, Z. Kurnatowska, A.M. Wyrwa (red.), Warszawa, Instytut Archeologii i Etnologii PAN.

Ostrów Lednicki. U progu chrześcijaństwa w Polsce, t. 1 i 2, 1993, K. Żurowska (red.), „Biblioteka Studiów Lednickich", t. 2, Kraków.

Ożóg K. 2016, 966. Chrzest Polski, Kraków, Biały Kruk.

Rębkowski M. 2007, Chrystianizacja Pomorza Zachodniego. Studium archeologiczne, Szczecin, Instytut Archeologii i Etnologii PAN.

Рябинин Е. А. 1981, Зооморфнье украшения древней Руси X-ХIV вв., „НАУКА”, Ленинград.

Rodzińska-Chorąży T. 2016, Stan badań nad architektura Ostrowa Lednickiego (1993-2015), w: Ostrów Lednicki. Rezydencjonalno-stołeczny ośrodek pierwszych Piastów, Z. Kurnatowska, A.M. Wyrwa (red.), Warszawa, Instytut Archeologii i Etnologii PAN, s. 143-171.

Sacrum pogańskie - Sacrum chrześcijańskie. Kontynuacja miejsc kultu we wczesnośredniowiecznej Europie Środkowej 2010, K. Bracha, Cz. Hadamik (red.), Warszawa, Wydawnictwo DiG.

Sawicki T. 2017, Przedchrześcijańska konstrukcja kamienna na Górze Lecha w Gnieźnie, w: Gemma Gemmarum. Studia dedykowane Profesor Hannie Kóčce-Krenz, Część pierwsza, A. Różański (red.), Wydawnictwo Poznańskiego Towarzystwa Przyjaciół Nauk, Poznań, s. 641-668.

Schuldt E. 1990, Der eintausendjährige Tempelort Gross Raden, Schwerin, Museum für Ur- und Frühgeschichte Schwerin.

Sikora J. 2010, Miejsca sacrum pogańskiego i chrześcijańskiego oraz procesy chrystianizacji Polski Centralnej we wczesnym średniowieczu, w: Sacrum pogańskie - Sacrum chrześcijańskie. Kontynuacja miejsc kultu we wczesnośredniowiecznej Europie Środkowej, K. Bracha, Cz. Hadamik (red.), Warszawa, Wydawnictwo DiG, s. 253-287.

Sikorski D.A. 2010, Od pogańskich sanktuariów do chrześcijańskich kościołów na Słowiańszczyźnie Zachodniej, w: Sacrum pogańskie - Sacrum chrześcijańskie. Kontynuacja miejsc kultu we wczesnośredniowiecznej Europie Środkowej, K. Bracha, Cz. Hadamik (red.), Warszawa, Wydawnictwo DiG, s. $405-427$. 
Słupecki L.P. 2000, Sanktuaria pogańskie w świecie natury u Słowian i Germanów. Święte gaje i ich bogowie, w: Człowiek, sacrum, środowisko. Miejsca kultu we wczesnym średniowieczu, S. Moździoch (red.), Wrocław, Instytut Archeologii i Etnologii PAN, Oddział we Wrocławiu, „Spotkania Bytomskie" 4, s. 39-47.

Słupecki L.P. 2006, Miejsca kultu pogańskiego w Polsce na tle badań nad wierzeniami Stowian, w: Stan i potrzeby badań nad wczesnym średniowieczem w Polsce - 15 lat później, W. Chudziak, S. Moździoch (red.), Toruń-Wrocław-Warszawa, Instytut Archeologii Uniwersytet Mikołaja Kopernika w Toruniu/Instytut Archeologii i Etnologii PAN, s. 63-82.

Strzelczyk J. 2007, Mity, podania i wierzenia dawnych Słowian, Poznań, Wydawnictwo REBIS Sp. z o.o.

Strzelczyk J. 2010, Kontynuacja miejsc kultu w teorii i praktyce wczesnośredniowiecznego Kościoła, w: Sacrum pogańskie - Sacrum chrześcijańskie. Kontynuacja miejsc kultu we wczesnośredniowiecznej Europie Środkowej, K. Bracha, Cz. Hadamik (red.), Warszawa, Wydawnictwo DiG, s. 13-25.

Strzyżewski Cz., Łastowiecki M., Kara M. 2003, Wczesnośredniowieczne grodzisko w Moraczewie pod Ostrowem Lednickim. Komunikat o wynikach badań archeologicznych w latach 1977-81, „Wielkopolskie Sprawozdania Archeologiczne", t. 6, s. 76-93.

Szafrański W., 1979, Pradzieje religii w Polsce, Warszawa, Iskry.

Szczepanik P. 2010, Przedmiot jako zapis porządku kosmologicznego Stowian Zachodnich. Analiza wybranych okuć pochewek noży, w: Życie codzienne przez pryzmat rzeczy, P. Kucypera, S. Wadyl (red.), Toruń, Wydawnictwo Naukowe Uniwersytetu Mikołaja Kopernika, s. 27-41.

Szyjewski A. 2010, Religia Stowian, Kraków, Wydawnictwo WAM.

Ślusarski K.W. 2004, Wczesnośredniowieczne pisanki i grzechotki z ziem polskich. Próba typologii, w: Hereditatem cognoscere. Studia i szkice dedykowane Profesor Marii Miśkiewicz, Z. Kobyliński (red.), Warszawa, IA UW/PMA, s. 79-110.

Wczesnośredniowieczne mosty przy Ostrowie Lednickim, t. 1. Mosty traktu gnieźnieńskiego 2000, Z. Kurnatowska (red.), „Biblioteka Studiów Lednickich”, t. 5, Muzeum Pierwszych Piastów na Lednicy, Lednica-Toruń.

Wczesnośredniowieczne mosty przy Ostrowie Lednickim, t. 2. Mosty Traktu Poznańskiego (wyniki archeologicznych badań podwodnych prowadzonych w latach 1986-2003), 2014, A. Kola, G. Wilke (red.), Kraków, Towarzystwo Autorów i Wydawców Prac Naukowych.

Wierzenia przedchrześcijańskie na ziemiach polskich, 1993. M. Kwapiński, H. Paner (red.), Gdańsk, Muzeum Archeologiczne w Gdańsku.

Wrzesińska A., Wrzesiński J. 1998, Grób konia z Dziekanowic, „Studia Lednickie” t. 5, s. 103-115.

Wrzesińska A., Wrzesiński J. 1998, Próba interpretacji struktury społecznej ludności na cmentarzysku. Doniesienia wstępne, „Studia Lednickie”, t. 5, s. 13-27.

Wrzesińska A., Wrzesiński J. 2005, Czytanie z kości, Lednica, Muzeum Pierwszych Piastów na Lednicy.

Wrzesińska A., Wrzesiński J. 2017, Gliniana grzechotka z Dziekanowic w Wielkopolsce, w: Fines testis temporum. Studia ofiarowane Profesor Elżbiecie Kowalczyk-Heyman w pięćdziesięciolecie pracy naukowej, Rzeszów, s. 339-344.

Wrzesiński J. 2000, Noże żelazne $w$ grobach na wczesnośredniowiecznym cmentarzysku w Dziekanowicach, „Studia Lednickie”, t. 6, s. 91-124.

Wrzesiński J. 2016, Archeologia dziekanowickich grobów z monetami, w: Nummus bonum fragile est. Groby z monetami wczesnośredniowiecznego cmentarzyska w Dziekanowicach, J. Wrzesiński (red.), Lednica, Muzeum Pierwszych Piastów na Lednicy, s. 13-106.

Wrzesiński J., Kara M. 2016, Chronologia i fazy użytkowania tzw. II kościoła na Ostrowie Lednickim, w: Ostrów Lednicki. Rezydencjonalno-stołeczny ośrodek pierwszych Piastów, Z. Kurnatowska, A.M. Wyrwa (red.), Warszawa, Instytut Archeologii i Etnologii PAN, s. 173-201.

Wrzosek A. 1961, Zabytki wczesnośredniowieczne z Ostrowa Lednickiego, pow. Gniezno, „Fontes Archeologii Posnanienses", t. 12, s. 242-253.

Żurowska K. 2016, Forma i usytuowanie basenów chrzcielnych w kaplicy na Ostrowie Lednickim, w: Miejsca chrztów, urządzenia baptyzmalne i ceremoniat chrzcielny od starożytności chrześcijańskiej do soboru trydenckiego (red.), A.M. Wyrwa, Wydawnictwo Poznańskiego Towarzystwa Przyjaciół Nauk, Poznań-Dziekanowice, s. 153-163. 